ISSN 1991-8631

Original Paper

http://indexmedicus.afro.who.int

\title{
Mucuna pruriens differentially affect maize yields in three soils of Kakamega District
}

\author{
Ajebesone Francis NGOME ${ }^{1^{*}}$, Kelvin Mark MTEI ${ }^{2}$ and Precillia Ijang TATA ${ }^{1}$ \\ ${ }^{1}$ Institute of Agricultural Research for Development (IRAD), B.P. 2123 Yaoundé, Cameroon. \\ ${ }^{2}$ College of Education, Dar es salaam University, P.O. Box 2329, Dar es salaam, Tanzania. \\ *Corresponding author, E-mail: ngomajebe@yahoo.com
}

\begin{abstract}
Maize production in smallholder farming systems in Kenya is largely limited by low soil fertility. As mineral fertilizer is expensive, green manuring using leguminous cover crops could be an alternative strategy for farmers to enhance farm productivity. However, due to variability in soil type, the effects of green manure are likely to differ with farms. This study was conducted in three contrasting soils in Kakamega District, Kenya, to evaluate Mucuna pruriens on (i) biomass and nitrogen fixation $\left({ }^{15} \mathrm{~N}\right.$ natural abundance) and (ii) the effects on maize yields over two cropping seasons. Mucuna at 6 weeks accumulated $1-1.3 \mathrm{Mg} \mathrm{ha}^{-1}$ of dry matter and 33-56 $\mathrm{kg} \mathrm{ha}^{-1}$ nitrogen of which approximately $70 \%$ was nitrogen derived from the atmosphere (Ndfa). Maize yield increased by $0.5-2 \mathrm{Mg} \mathrm{ha}^{-1}, 0.7-2 \mathrm{Mg} \mathrm{ha}^{-1}$ and $1.5-4 \mathrm{Mg}^{-1}$ with Mucuna, farmyard manure and mineral fertilizer use, respectively, and the response was stronger in Nitisol than in Acrisol or Ferralsol. We concluded that green manuring using Mucuna seem promising in enhancing soil fertility and maize yields in Kakamega, provided soil conditions and rainfall are suitable.
\end{abstract}

(c) 2012 International Formulae Group. All rights reserved.

Keywords: Acrisol, Ferralsol, green manure, Nitisol, nitrogen fixation.

\section{INTRODUCTION}

The generally low maize yield in smallholder farming systems in Western Kenya is attributed to a decline in soil fertility (Okalebo et al., 2006; Ngome et al., 2011). Recommendations made by scientists to enhance soil fertility include mineral fertilizer use and the addition of animal manure (Tittonell et al., 2008; Shisanya et al., 2009). Whereas mineral fertilizer may be expensive for most smallholder farmers (Nambiro, 2008), the use of manure is limited because (i) it is not sufficiently available particularly at the recommended application rates $(5-10 \mathrm{Mg}$ $\mathrm{ha}^{-1}$ ), (ii) it is bulky and labor-intensive for transportation and application, and (iii) its quality is often poor (Odendo et al., 2006, Diwani, 2009). In the last decades, the use of leguminous cover crops has been widely promoted as an alternative strategy to enhance soil fertility in croplands (Nambiro, 2008; Tejada et al., 2008). In Africa, the use of cover crop legumes to increase maize production has received substantial attention. Species like Mucuna pruriens have been used successfully to control weeds and improve farm productivity in West Africa (Carsky et al., 2001; Naudin et al., 2010). Similarly, 
scientists from Uganda, East Africa, acknowledged an increase in maize grain yield of 0.4 to $1.0 \mathrm{Mg} \mathrm{ha}^{-1}$ over farmers' practice due to incorporation of 22 weeks old Mucuna pruriens (Kaizzi et al., 2006).

In Western Kenya, the smallholder farming system is characterized by a large diversity in soil type, cropping systems and available resources that create gradients in soil fertility both between and within farms (Tittonell et al., 2008; Diwani, 2009). Thus, the effectiveness of cover crop legumes to improve maize production is likely to differ with farms. This study was conducted on three contrasting soil types of Kakamega District, Western Kenya (i) to determine biomass and nitrogen fixation by Mucuna and (ii) to evaluate the effects of Mucuna on maize yields over two cropping seasons.

\section{MATERIALS AND METHODS Experimental sites}

This study was conducted between 2008 and 2009 at three sites of Kakamega District, Western Kenya namely (i) the Kenya Agricultural Research Institute (KARI) in Kakamega, (ii) Lubao in the Ileho division and (iii) Virhembe in Shinyalu division (Figure 1). All three sites are situated within a 2-30 km distance from Kakamega town (034 ${ }^{\circ}$ 46' E latitude, $00^{\circ} 17^{\prime} \mathrm{S}$ longitude). The three sites have contrasting soil types namely eutric Nitisol (KARI), ferralo-orthic Acrisol (Lubao) and nito-rhodic Ferralsol (Virhembe), according to the FAO classification (FAO, 1990). The soils differed in chemical properties (Table 1), while climatic conditions were similar. Mean temperature of the three localities was $21{ }^{\circ} \mathrm{C}$ and mean annual rainfall ranged from 1600 to $2200 \mathrm{~mm}$ with a distinct bimodal pattern. Maize is grown both in the short rainy season (August to November) and in the long rainy season (March to July). The study on Nitisol was conducted on a research farm at KARI where maize varietal trials have been previously conducted with regular application of mineral fertilizer. Trials on Acrisol and Ferralsol were conducted in farmers' fields where maize and common bean were grown for $>10$ years prior to this study. The study sites will subsequently be referred to by their soil types as Nitisol, Acrisol and Ferralsol.

\section{Trial design and management}

The experimental fields were under a weedy fallow that was cleared using cutlasses and tilled manually using a hand hoe. There were four treatments that were assessed in a randomized complete block design. The experimental plots were $6 \times 5 \mathrm{~m}$ separated by $0.5 \mathrm{~m}$ borders. The treatments included (i) Farmer's practice (control treatment), without external input use, (ii) Farmyard manure, where farmyard manure was incorporated at a rate of $5 \mathrm{Mg} \mathrm{ha}^{-1}$ during land preparation, (iii) Mucuna as green manure, whereby Mucuna pruriens var. Utilis was established two weeks prior to maize seeding at the onset of the short (20 August 2008) and the long rainy season (8 March 2009) at a 20x30 cm spacing. A basal $\mathrm{P}$ application of $30 \mathrm{~kg} \mathrm{ha}^{-1}$ was applied to Mucuna as triple superphosphate at planting. Mucuna biomass was incorporated six weeks after seeding between the rows of 4 weeks-old maize using a hand hoe. (iv) Mineral fertilizer, where mineral $\mathrm{N}$ was applied to maize as urea at a rate of $100 \mathrm{~kg} \mathrm{ha}^{-1}$ with 40,30 and $30 \%$ provided at planting, four weeks and six weeks after maize seeding, respectively. A basal application of $100 \mathrm{~kg} \mathrm{P} \mathrm{ha}^{-1}$ was applied as triple super phosphate at maize seeding.

Maize variety HB 520 was seeded in all treatment plots on $4^{\text {th }}$ September 2008 for the short and on $22^{\text {nd }}$ March 2009 for the long rainy season crop at a $60 \times 25 \mathrm{~cm}$ spacing. Two maize seeds were used per planting hole and thinned to one plant per hill two weeks after emergence. Weeds were manually removed at 14, 28 and 42 days after maize seeding. 


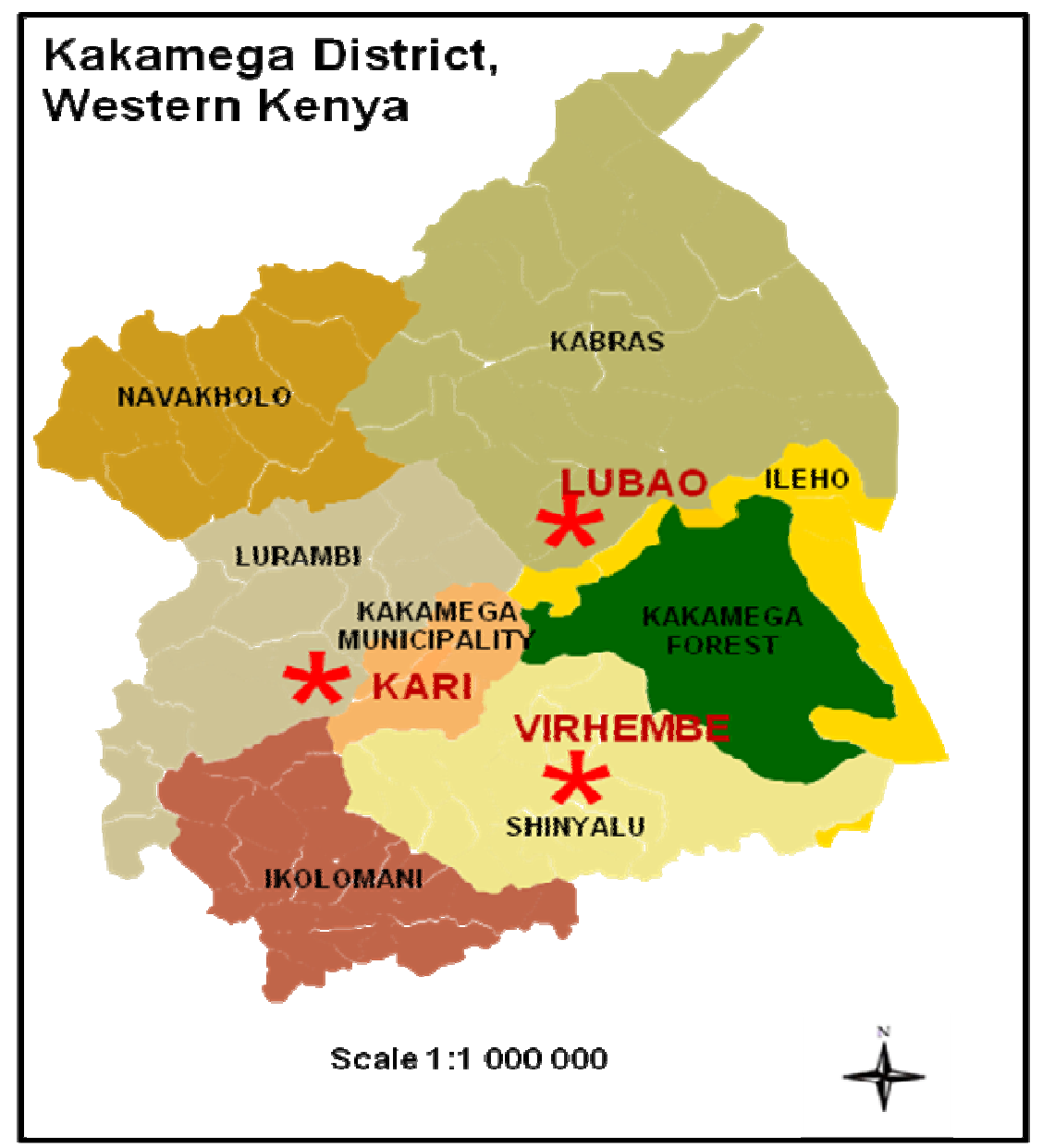

Figure 1: Map of Kakamega District, Kenya, showing divisions and the experimental sites.

\section{Data collection and calculation}

The above-ground biomass of Mucuna was determined at six weeks after seeding in both cropping seasons. Mucuna plants in each treatment plot were cut at ground level and weighed (including litter) to obtain the total fresh weight. Sub samples of $500 \mathrm{~g}$ were oven-dried at $70{ }^{\circ} \mathrm{C}$ until constant weight. The dried sub samples were finely ground $(1 \mathrm{~mm})$ and kept until analysis. Five milligram sample was weighed from each ground Mucuna sample and analyzed for nitrogen (N) concentration with an automatic elemental analyzer (EA Euro 3000). Phosphorus (P) and potassium (K) concentration in Mucuna were measured after dry-ashing and extraction with $6 \mathrm{M} \mathrm{HCl}$ (Mussgnug et al., 2006). P was measured colorimetrically with a spectrophotometer (Eppendorf ECOM 6122). $\mathrm{K}$ was measured with a flame photometer (Eppendorf Elex 6361). The percentage of nitrogen derived from the atmosphere (\% Ndfa) of Mucuna was estimated by the Delta-15 Natural Abundance Method $\left({ }^{15} \mathrm{NNAM}\right)$ as in equation (1) and the proportions of $\mathrm{N}$ obtained from the 
Table 1: Climatic conditions and soil characteristics of three contrasting sites of Kakamega District, Western Kenya.

\begin{tabular}{|c|c|c|c|}
\hline \multirow{2}{*}{ Parameter } & \multicolumn{3}{|c|}{ Soil type } \\
\hline & KARI & Lubao & Virhembe \\
\hline Altitude (masl) & 1534 & 1558 & 1569 \\
\hline Latitude & $\mathrm{N} 00^{\circ} 16.962^{\prime}$ & $\mathrm{N} 00^{\circ} 19.180^{\prime}$ & $\mathrm{N} 00^{\circ} 14.548^{\prime}$ \\
\hline Longitude & E $034^{\circ} 46.073^{\prime}$ & E $034^{\circ} 47.793^{\prime}$ & E $034^{\circ} 51.129^{\prime}$ \\
\hline Annual rainfall (mm) & 1978 & 1612 & 2232 \\
\hline Mean temperature $\left({ }^{\circ} \mathrm{C}\right)$ & 21 & 21 & 21 \\
\hline Soil type & eutric nitisol & orthic acrisol & rhodic ferralsol \\
\hline Soil texture & Clay-loam & Sandy-loam & Clay \\
\hline Sand $(\%)$ & 12.9 & 61.2 & 10.8 \\
\hline Silt (\%) & 33.6 & 20.0 & 27.0 \\
\hline Clay $(\%)$ & 53.5 & 18.8 & 62.2 \\
\hline $\mathrm{pH}\left(\mathrm{H}_{2} \mathrm{O}\right)$ & 5.4 & 5.4 & 4.9 \\
\hline Total C (\%) & 4.1 & 1.4 & 3.0 \\
\hline Total N (\%) & 0.3 & 0.1 & 0.2 \\
\hline Available Bray-P $\left(\mathrm{mg} \mathrm{kg}^{-1}\right)$ & 3.4 & 7.7 & 2.3 \\
\hline Exchangeable $\mathrm{K}\left(\mathrm{cmol} \mathrm{kg}^{-1}\right)$ & 0.7 & 0.2 & 0.8 \\
\hline
\end{tabular}

Soil analysis method: Okalebo et al. (2002).

atmosphere (Ndfa) and from the soil (Ndfs) were calculated as in equation (2) (Gathumbi et al., 2002). Total $\mathrm{N}$ accumulated by Mucuna was calculated as the sum of Ndfa and Ndfs. Maize in the treatment plots was used as reference crop for ${ }^{15} \mathrm{~N}$ analysis. The B-value (natural discrimination of heavy ${ }^{15} \mathrm{~N}$ isotope by nitrogenase enzyme complex) of $1.64 \%$ o was used (Gathumbi et al., 2002).

$\% \operatorname{Ndfa}=\left(\frac{\delta^{15} \mathrm{~N}_{\text {maize }}-\delta^{15} \mathrm{~N}_{\text {Mucuna }}}{\delta^{15} \mathrm{~N}_{\text {maize }}-\mathrm{B}}\right) \times 100 \ldots . . .(1)$

$\mathrm{Ndfa}=\left(\frac{\% \mathrm{Ndfa}}{100}\right) \times$ quantityof Nin DM...

whereby B represents the $\delta^{15} \mathrm{~N}$ of Mucuna grown in $\mathrm{N}$-free medium, DM is total dry matter of Mucuna and \%Ndfs $=100-\%$ Ndfa.

Maize grain yield was determined 16 weeks after seeding by harvesting an area of $1.2 \times 2 \mathrm{~m}$ in two replicates in the middle rows of each treatment plot. The maize cobs were harvested, dried and threshed, and yield was reported at $14 \%$ moisture content.

\section{Statistical analysis}

Data generated on the biomass, nutrient concentration and nitrogen fixation of Mucuna, and maize yields were subjected to analysis of variance (ANOVA) using the SPSS statistical package (SPSS, 2008) while mean separation was done by Tukey test $(\mathrm{P}<0.05)$.

\section{RESULTS}

\section{Biomass and nitrogen fixation by Mucuna pruriens}

The above-ground dry matter (DM) of Mucuna significantly $(\mathrm{p}<0.05)$ differed across soils during the short rainy season but was not the case during the long rainy season (Table 2). The DM was approximately 10 to $20 \%$ higher in the long than in the short rainy season and was highest on the Acrisol and lowest on the Ferralsol.

The nutrient concentration of Mucuna also differed across soils and seasons (Table $2)$. While significant differences $(p<0.05)$ were observed for nitrogen and potassium contents, no such difference was observed 
with phosphorus. The mean values of the nutrients were $3.3-4.6 \%, 0.32-0.34 \%$ and $0.25-0.32 \%$ for $\mathrm{N}, \mathrm{P}$ and $\mathrm{K}$, respectively.

The percentage $\mathrm{N}$ obtained from the atmosphere (\%Ndfa) by Mucuna was similar across soils and seasons. However, significant differences $(\mathrm{p}<0.05)$ in $\% \mathrm{Ndfs}$ were observed across the soils during the long rainy season (Table 3).

Approximately 68-70\% $\mathrm{N}$ was derived by Mucuna from the atmosphere and the remainder from the soil. Total $\mathrm{N}$ accumulated by Mucuna differed slightly across sites and seasons (Figure 2). Mucuna accumulated 10$18 \mathrm{~kg} \mathrm{~N} \mathrm{ha}^{-1}$ particularly in the Nitisol during the long rainy season.

\section{Effect of treatments on maize yields}

Maize grain yield significantly $(\mathrm{P}<0.001)$ increased with farmyard manure addition, incorporation of Mucuna pruriens and mineral fertilizer use compared to the farmer practice across the soils and in both the short and the long rainy seasons (Figure 3 ). The yield was > $50 \%$ higher in the long than in the short rainy season particularly in the Nitisol. Mineral fertilizer use showed the strongest positive effect on maize grain yield across the soils, which was 1.5-4.0 $\mathrm{Mg} \mathrm{ha}^{-1}$ more than the farmer practice. Response of maize to green manuring differed across soils with the highest yields observed in the Nitisol (2.3-4.9 $\mathrm{Mg} \mathrm{ha}{ }^{-1}$ ) and lowest in the Acrisol (1.4-1.8 $\left.\mathrm{Mg} \mathrm{ha}^{-1}\right)$. Generally, the response of maize to farmyard manure addition did not differ significantly from green manuring using Mucuna, irrespective of the soil type.

Table 2: Above-ground dry matter (DM) accumulation and nutrient concentration of six-weeks old Mucuna pruriens var. utilis on three contrasting soil types in Kakamega District, Kenya, during the short rainy season of 2008 and the long rainy season of 2009.

\begin{tabular}{lcccccc}
\hline & \multicolumn{3}{c}{ Short rainy season 2008 } & \multicolumn{3}{c}{ Long rainy season 2009 } \\
\hline Parameter & Nitisol & Acrisol & Ferralsol & Nitisol & Acrisol & Ferralsol \\
\hline DM $\left(\mathrm{Mg} \mathrm{ha}^{-1}\right)$ & $1.00 \mathrm{ab}$ & $1.20 \mathrm{a}$ & $0.90 \mathrm{~b}$ & $1.20^{\mathrm{ns}}$ & 1.30 & 1.10 \\
Nitrogen $(\%)$ & $4.10 \mathrm{a}$ & $3.30 \mathrm{c}$ & $3.60 \mathrm{~b}$ & $4.60 \mathrm{a}$ & $4.00 \mathrm{~b}$ & $4.30 \mathrm{ab}$ \\
Phosphorus $(\%)$ & $0.33^{\mathrm{ns}}$ & 0.34 & 0.32 & $0.34^{\mathrm{ns}}$ & 0.34 & 0.34 \\
Potassium $(\%)$ & $0.32 \mathrm{a}$ & $0.26 \mathrm{~b}$ & $0.32 \mathrm{a}$ & $0.30 \mathrm{a}$ & $0.25 \mathrm{~b}$ & $0.29 \mathrm{a}$ \\
\hline
\end{tabular}

Means of a parameter with the same letter in a season are not significantly different at $p<0.05$ by Tukey Test; ns: nonsignificantly different at $\mathrm{p}<0.05$.

Table 3: Percentage of $\mathrm{N}$ derived from the atmosphere (\%Ndfa) and from the soil (\%Ndfs) by 6 weeks old Mucuna pruriens var. utilis on three contrasting soil types in Kakamega, Kenya, during the short rainy season of 2008 and the long rainy season of 2009.

\begin{tabular}{lccc}
\hline Crop and season & Soil type & \% Ndfa & \% Ndfs \\
\hline Mucuna & Nitisol & $70.0 \pm 3.3^{\text {ns }}$ & $30.0^{\mathrm{ns}}$ \\
Short rainy season & Acrisol & $68.9 \pm 2.7$ & 31.1 \\
& Ferralsol & $67.5 \pm 0.4$ & 32.5 \\
Mucuna & Nitisol & $70.1 \pm 3.2^{\text {ns }}$ & $29.9 \mathrm{~b}$ \\
Long rainy season & Acrisol & $68.8 \pm 2.7$ & $31.2 \mathrm{ab}$ \\
& Ferralsol & $68.0 \pm 0.5$ & $32.0 \mathrm{a}$
\end{tabular}

Means with the same letter in a season are not significantly different at $\mathrm{p}<0.05$ by Tukey Test; ns: non-significant at $\mathrm{p}<0.05$. 
Short rainy season (2008)

Long rainy season (2009)

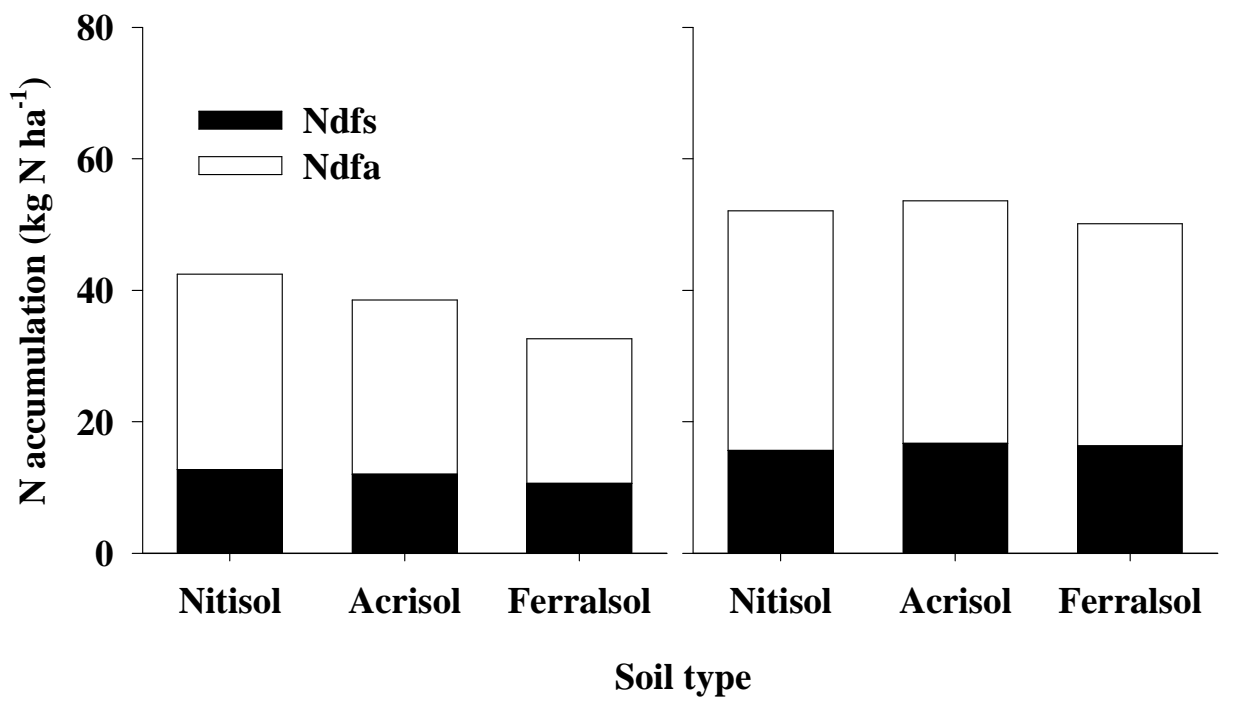

Figure 2: Nitrogen accumulation of six weeks old Mucuna pruriens var. utilis on three contrasting soil types of Kakamega, Kenya, in the short rainy season of 2008 and the long rainy season of 2009.

Short rainy season of 2008

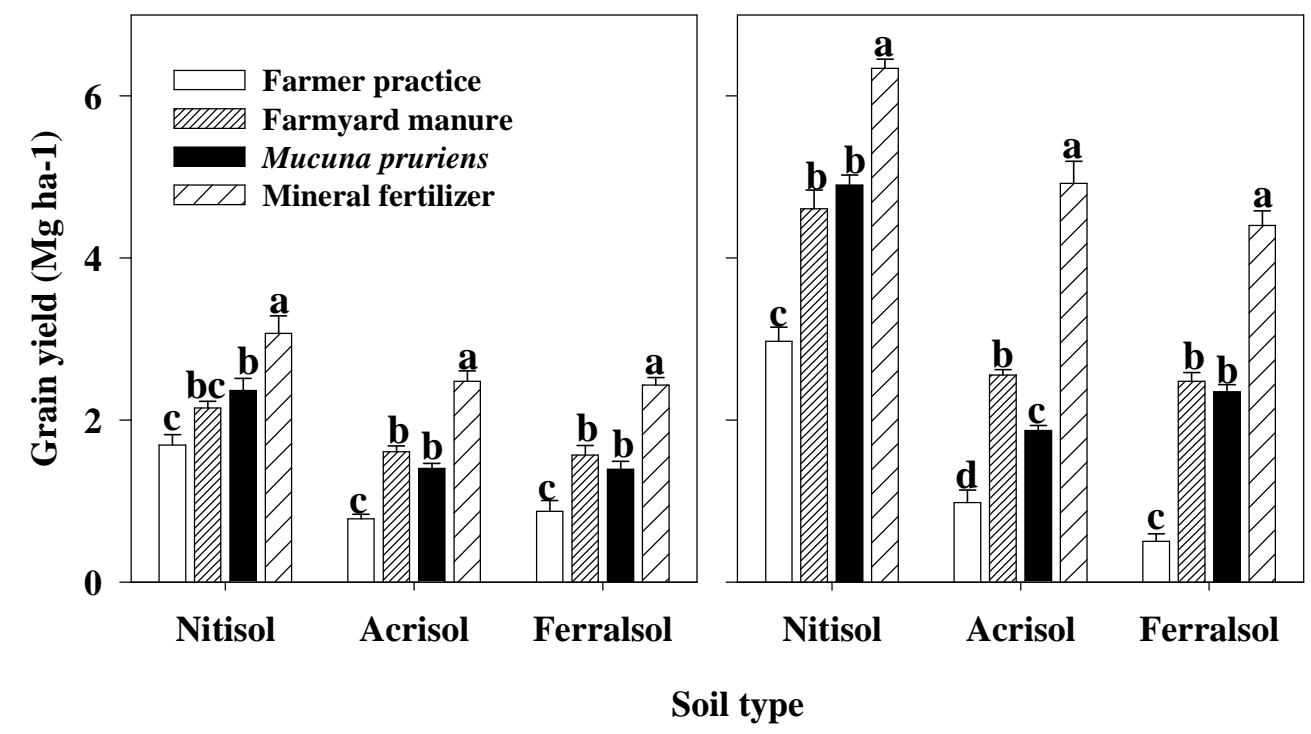

Figure 3: Response of maize grain yield to Mucuna pruriens var. utilis on three contrasting soil types in Kakamega, Kenya, during the short rainy season of 2008 and the long rainy season of 2009. Bars are standard error of the means $(n=4)$. Treatments with the same letter in a soil type are not significantly different by Tukey $(\mathrm{P}<0.05)$. Farmer practice: no input control treatment, Farmyard manure: farmyard manure incorporation at a rate of 5 $\mathrm{Mg} \mathrm{ha}^{-1}$, Mucuna pruriens: green manuring using Mucuna, Mineral fertilizer: application of mineral $\mathrm{N}$ and $\mathrm{P}$ at a rate of 100 $\mathrm{kg} \mathrm{ha}^{-1}$ each. 


\section{DISCUSSION}

The aim of this study was to assess the effects of green manuring by Mucuna pruriens on maize yields in Kakamega District, Kenya. Although the study provides only a short-term assessment of the effects of Mucuna on maize yields, it demonstrated that soil type and cropping seasons differentially affect the effectiveness of cover legumes to improve farm productivity.

\section{Effects of seasonal rainfall and soil type on Mucuna}

In tropical farming systems, seasonal rainfall availability is known to influence the performance of cover legumes in terms of biomass accumulation (Hauser and Nolte, 2002). Similarly, variability in soil type is reported to influence biological nitrogen fixation in smallholder farming systems (Ngome and Mtei, 2010). Thus, the generally higher biomass and nitrogen accumulated by Mucuna in the Acrisol and the Nitisol than in the Ferralsol, was probably because the Ferralsol was clay-textured and highly acidic with the possibility of fixing P (George et al., 2002), unlike the other soil types. In an earlier study, Kaizzi et al., 2006 observed that Mucuna does not grow very well on clayey and highly acidic soils.

The nutrient contents in the biomass of Mucuna were also influenced by soil type. This explains why $\mathrm{N}$ and $\mathrm{K}$ concentrations tended to be higher in the Nitisol and the Ferralsol than in the Acrisol while $\mathrm{P}$ concentrations tended to be highest in the Acrisol and lowest in the Ferralsol, irrespective of the season. Similar results were obtained with the cover legume Arachis pintoi in Western Kenya (Ngome and Mtei, 2010).

This study confirms that a considerable amount of nitrogen could be obtained from biological nitrogen fixation by legumes as earlier reported (Giller, 2001) and as such could be a low cost alternative to mineral fertilizer particularly for small-scale farmers in Kakamega District. However, the amount of $\mathrm{N}$ accumulation could largely depend on the soil type due to variability in inherent soil attributes particularly phosphorus (Ngome, 2009).

In this study, a basal $\mathrm{P}$ application was done before seeding Mucuna, as the level of $\mathrm{P}$ in the soils was very low $\left(<6 \mathrm{mg} \mathrm{P} \mathrm{kg}{ }^{-1}\right)$. This suggests that to obtain benefits from nitrogen fixation by Mucuna, farmers in Kakamega District would need to apply mineral or organic $\mathrm{P}$ in their farms. $\mathrm{P}$ is essential in nitrogen fixation and the application of $\mathrm{P}$ is widely reported to have a significant positive effect on biomass accumulation, nodulation and nitrogen fixation in legumes (Somado et al., 2003; Kifuko et al., 2007). The P applied to the legume is recycled together with the fixed $\mathrm{N}$ during incorporation of biomass (Giller et al., 2009), which may stimulate the systems productivity (Somado et al., 2003).

\section{Effect of Mucuna on maize yield}

The current study supports earlier findings that increased maize production in smallholder farming systems can be achieved using leguminous cover crops (Kaizzi et al., 2006; Tejada et al., 2008). The study further demonstrated the possibility of growing Mucuna and maize simultaneously in the same piece of land before the Mucuna is incorporated between maize rows. Previously, scientists recommended planting of leguminous cover crops like Mucuna solely during the short rainy season and incorporating them before seeding maize in the following long rainy season (Carsky et al., 2001). However, most farmers in Kenya are very reluctant to implement this technology because the practice requires a sacrifice of one season maize crop (Rao and Mathuva, 2000). This finding is therefore relevant in smallholder farming systems of Kenya where rainfall is sufficiently available and farmers grow maize continuously on the same piece of land. Additionally, this study illustrated that the magnitude of the effect of leguminous cover crops on maize yields is likely to depend on soil type and seasonal rainfall patterns. In cropping seasons with frequent 
dry spells, maize yields may reduce due to competition from leguminous cover crops (Mathuva et al., 1998; Diwani, 2009). This situation may be compounded in sandy soils (e.g. Acrisol) due to the low water-holding capacity (Brady and Weil, 2002). In such situations, farmyard manure addition could be a promising option for smallholder farmers to improve maize yields, as observed in the Acrisol in this study. Finally, this study confirmed that mineral fertilizer application remains vital for improving maize productivity in Western Kenya, although the high financial requirements involved may limit mineral fertilizer use by farmers.

\section{Conclusion}

We can conclude that green manuring using Mucuna pruriens has the potential to increase maize yields in Kakamega District, although this may depend largely on soil attributes such as $\mathrm{P}$ and seasonal rainfall availability. Additional studies on the social economic implications of introducing Mucuna into the smallholder farming systems of Kakamega District are underway.

\section{ACKNOWLEDGEMENTS}

This study was financed by the German Federal Ministry of Education and Research (BMBF) through the 'Biodiversity Monitoring Transect Analysis in Africa' (BIOTA) Project and the German Catholic Exchange Service (KAAD). The institutional support from IRAD of Cameroon, KARI Kakamega of Kenya,University of Bonn and University of Dar es salaam is acknowledged.

\section{REFERENCES}

Brady NC, Weil RR. 2002. The Nature and Properties of Soils $\left(13^{\text {th }}\right.$ edn). Pearson Educational: New Jersey, USA; 960.

Carsky RJ, Becker M, Hauser S. 2001. Mucuna cover crop fallow systems: potential and limitations. In Sustaining Soil Fertility in West Africa, Tian G, Ishida F, Keatinge D (eds). SSSA Spec.
Publ. 58. SSSA and ASA: Madison, WI, USA; 111-135.

Diwani T. 2009. Implications of resource management on soil fertility in common farm types in Kakamega, Western Kenya. PhD thesis, Bonn University, Bonn, p.178.

FAO. 1990. FAO-UNESCO soil map of the world. Revised legend. World resources report No. 60. Food and Agricultural Organization, Rome, Italy.

Gathumbi SM, Cadisch G, Giller KE. 2002. $15 \mathrm{~N}$ natural abundance as a tool for assessing $\mathrm{N}_{2}$-fixation of herbaceous, shrub and tree legumes in improved fallows. Soil Biol. Biochem., 34: 10591071.

George TS, Gregory BJ, Robinson JS, Buresh RJ, Jama B. 2002. Utilization of soil organic phosphorus from oxisols in relation to phosphatase activities in the rhizosphere. Euro. J. Soil Sci., 57: 47-57.

Giller KE. 2001. Nitrogen Fixation in Tropical Cropping Systems. Willingford $\mathrm{CAB}$ International: Wallingford, UK; 448.

Giller KE, Witter E, Corbeels M, Tittonell P. 2009. Conservation agriculture and smallholder farming in Africa: The heretics' view. Field Crops Res., 114: 23-34.

Hauser S, Nolte C. 2002. Biomass production and $\mathrm{N}$ fixation of five Mucuna pruriens varieties and their effects on maize yields in the forest zone of Cameroon. $J$. Plant Nutr. Soil Sci., 165: 101-109.

Kaizzi CK, Ssali H, Vlek PLG. 2006. Differential use and benefits of Velvet bean (Mucuna pruriens var. utilis) and $\mathrm{N}$ fertilizers in maize production in contrasting agro-ecological zones of East Uganda. Agric. Syst., 88: 44-60.

Kifuko MN, Othieno CO, Okalebo JR, Kimenye LN, Ndung'u KW, Kipkoech AK. 2007. Effect of combining organic residues with Minjingu phosphate rock on sorption and availability of phosphorus and maize production in acid 
soils of Western Kenya. Expl. Agric., 43: 51-66.

Mathuva MN, Rao MR, Smithson PC, Coe R. 1998. Improving maize (Zea mays) yields in semi arid highlands of Kenya: agroforestry or inorganic fertilizers. Field Crops Res., 55: 57-72.

Mussgnug F, Becker M, Son TT, Buresh RJ, Vlek PLG. 2006. Yield gaps and nutrient balances in intensive, rice-based cropping systems on degraded soils in the Red River Delta of Vietnam. Field Crops Res., 98: 127-140.

Nambiro E. 2008. Trends in land use and agricultural intensification in Kakamega, Western Kenya. PhD thesis, Bonn University, Bonn, p. 132.

Naudin K, Goze E, Balarabe O, Giller KE, Scopel E. 2010. Impact of no tillage and mulching practices on cotton production in North Cameroon. A multi-locational on-farm assessment. Soil Tillage Res., 108: $68-76$.

Ngome AF. 2009. Effects of organic and inorganic phosphorus sources on nitrogen fixation by field grown common bean on an Alfisol and an Ultisol in Kakamega, Kenya. Int. J. Biol. Chem. Sci., 3: 168-177.

Ngome AF, Becker M, Mtei KM, Mussgnug F. 2011. Fertility management for maize cultivation in some soils of Western Kenya. Soil Tillage Res., 117: 69-75.

Ngome AF, Mtei KM. 2010. Establishment, biological nitrogen fixation and nutritive value of Arachis pintoi (CIAT 18744) in Western Kenya. Trop. Grasslands, 44: 289-294.

Odendo J, Ojiem J, Bationo A, Mudeheri M. 2006. On-farm evaluation and scaling-up of soil fertility management technologies in western Kenya. Nutr. Cycl. Agroecosyst., 76: 369-381.

Okalebo JR, Gathua KW, Woomer PL. 2002. Laboratory Methods of Soil and Plant Analysis: A Working Manual. TSBF: Nairobi, Kenya; 128.

Okalebo JR, Othieno CO, Woomer PL, Karanja NK, Semoka JRM, Bekunda MA, Mugendi DN, Muasya RM, Bationo A, Mukhwana EJ. 2006. Available technologies to replenish soil fertility in East Africa. Nutr. Cycl. Agroecosyst., 76: 153-170.

Rao MR, Mathuva MN. 2000. Legumes for improving maize yields and income in semi-arid Kenya. Agric. Ecosyst. Environ., 78: 123-137.

Somado EA, Becker M, Kuehne RF, Sahrawat KL, Vlek PLG. 2003. Combined effects of legumes with rock phosphorus on rice in West Africa. Agron. J., 95: 11721178.

Shisanya CA, Mucheru MW, Mugendi DN, Kung'u J. 2009. Effect of organic and inorganic nutrient sources on soil mineral nitrogen and maize yields in Central highlands of Kenya. Soil Tillage Res., 103: 239-246.

SPSS. 2008. SPSS version 17.0 for windows, SPSS Inc., Chicago, USA.

Tejada M, Gonzalez JM, Garcia-Martinez AM, Parrado J. 2008. Effects of different green manures on soil biological properties and maize yield. Bioresource Technol., 99: 1758-1767.

Tittonell P, Vanlauwe B, Corbeel M, Giller KE. 2008. Yield gaps, nutrient use efficiencies and response to fertilizers by maize across heterogeneous smallholder farms of western Kenya. Plant Soil, 313: 19-37. 